\title{
Analisis Kestabilan dan Bifurkasi Model Oregonator dari Reaksi Belousov - Zhabotinsky
}

\author{
Amelia M. S., Erna Apriliani, dan I Gst Ngr Rai Usadha \\ Departemen Matematika, Fakultas Matematika, Komputasi dan Sains Data, \\ Institut Teknologi Sepuluh Nopember (ITS) \\ e-mail: april@matematika.its.ac.id
}

\begin{abstract}
Abstrak-Reaksi Belousov - Zhabotinsky merupakan reaksi yang berosilasi, dimana osilasi yang terjadi pada reaksi ini memiliki kemiripan dengan osilasi yang terjadi pada sistem biologi seperti gelombang elektromagnetik pada jaringan jantung, saraf maupun otot. Reaksi ini memiliki perilaku dinamik yang menarik untuk dikaji melalui analisis kestabilan dan bifurkasi. Selain untuk mengetahui perilaku dinamik suatu sistem, analisis mengenai kestabilan dan bifurkasi juga dapat digunakan untuk mengetahui faktor apa yang mempengaruhi terjadinya osilasi pada sistem tersebut. Analisis kestabilan dapat dilakukan dengan menggunakan kriteria kestabilan nilai eigen dan Routh - Hurwitz, sementara untuk analisis bifurkasi dilakukan dengan menggunakan teorema bifurkasi Hopf. Dari hasil analisis didapatkan bahwa osilasi terjadi ketika nilai koefisien stokiometri Cerium(IV) berada pada rentang $\frac{1}{4}<f<$ $\frac{1}{2}$. Hasil yang didapatkan ini selanjutnya disimulasikan menggunakan MATLAB.
\end{abstract}

Kata Kunci-Bifurkasi, Kestabilan, Oregonator.

\section{PENDAHULUAN}

S ELAMA 150 tahun terakhir keterkaitan antara ilmu biologi dan ilmu kimia menjadi semakin kuat, dimulai dengan munculnya kimia organik dan berlanjut dengan biokimia. Ilmu kimia tidak hanya sekedar menyediakan pemahaman tentang dasar - dasar molekuler pada fenomena biologi, tetapi juga dapat menyediakan model dinamik untuk sistem biologi meskipun dasar yang ada dalam kedua sistem sangat berbeda. Hal ini didukung dengan teori kompleksitas yang menyatakan bahwa meskipun sistem - sistem tersebut mempunyai dasar yang berbeda, seringkali sistem - sistem tersebut memiliki karakteristik dinamik yang sama yang dapat dianalisis dan dimodelkan [1]. Salah satu contohnya adalah reaksi Belousov - Zhabotinsky $(\mathrm{B}-\mathrm{Z})$ yang dapat digunakan untuk memodelkan sistem biologi.

Reaksi Belousov - Zhabotinsky merupakan suatu reaksi osilasi yang dianggap sebagai purwarupa osilator. Osilasi yang terjadi pada reaksi Belousov - Zhabotinsky memiliki kemiripan dengan osilasi yang terjadi pada sistem biologis lain, seperti pada gelombang gerak elektromagnetik pada jaringan otot, jaringan saraf, dan agregasi jamur lendir [2].

Penelitian mengenai reaksi osilator telah membuka kesempatan bagi para peneliti untuk mengembangkan penerapan dari teori persamaan diferensial. Dalam penelitian yang dilakukan oleh Field, Körös dan Noyes, didapatkan suatu model matematika berupa sistem persamaan diferensial yang dapat menggambarkan perilaku osilasi yang terjadi pada reaksi Belousov - Zhabotinsky [2]. Reaksi kimia dapat dianggap sebagai suatu sistem yang perilaku dinamiknya dapat dikaji. Dalam reaksi Belousov - Zhabotinsky ini perilaku dinamik yang menarik untuk dikaji adalah bagaimana perubahan osilasi yang terjadi seiring dengan perubahan waktu serta bagaimana perilaku sistem apabila nilai parameter tertentu berubah. Osilasi yang terjadi mungkin akan menghilang atau membesar seiring dengan berjalannya waktu, dimana dalam teori matematika sistem perilaku ini disebut sebagai kestabilan sistem. Perubahan perilaku sistem akibat perubahan nilai parameter disebut sebagai bifurkasi, dimana masalah ini memiliki kaitan yang erat dengan kestabilan sistem. Selain untuk mengetahui perilaku dinamik suatu sistem, analisis mengenai kestabilan dan bifurkasi juga dapat digunakan untuk mengetahui faktor apa yang mempengaruhi terjadinya osilasi pada sistem tersebut.

Penelitian ini akan dilakukan dalam beberapa tahap. Pertama akan dilakukan studi literatur, dilanjutkan dengan penentuan titik setimbang, pelinieran sistem, uji kestabilan menggunakan kriteria nilai eigen dan Routh - Hurwitz. Setelah kestabilan sistem didapatkan, akan dilanjutkan dengan analisis bifurkasi yang terdiri dari penentuan parameter bifurkasi, pembuktian bahwa terjadi bifurkasi Hopf, serta penentuan rentang nilai parameter bifurkasi yang menyebabkan sistem tidak stabil. Hasil yang didapat selanjutnya akan disimulasikan menggunakan MATLAB sehingga bisa diambil kesimpulan dari hasil analisis serta simulasinya.

\section{II.URAIAN PENELITIAN}

\section{A. Kinetika Kimia}

Laju dari reaksi

$$
a A+b B \rightarrow c C+d D
$$

diberikan oleh

$$
\text { laju }=-\frac{1}{a} \frac{\Delta[A]}{\Delta t}=-\frac{1}{b} \frac{\Delta[B]}{\Delta t}=\frac{1}{c} \frac{\Delta[C]}{\Delta t}=\frac{1}{d} \frac{\Delta[D]}{\Delta t}
$$

Dengan hukum laju, didapatkan

laju $=k[A]^{x}[B]^{y}$

Sehingga laju perubahan konsentrasi menjadi

$\frac{\Delta[A]}{\Delta t}=-a k[A]^{x}[B]^{y}$

$\frac{\Delta[B]}{\Delta t}=-b k[A]^{x}[B]^{y}$

$\frac{\Delta[C]}{\Delta t}=\operatorname{ck}[A]^{x}[B]^{y}$

$\frac{\Delta[D]}{\Delta t}=d k[A]^{x}[B]^{y}$

Laju perubahan konsentrasi tersebut dapat ditulis sebagai suatu sistem persamaan diferensial

$\dot{A}=-a k[A]^{x}[B]^{y}$

$\dot{B}=-b k[A]^{x}[B]^{y}$

$\dot{C}=\operatorname{ck}[A]^{x}[B]^{y}$

$\dot{D}=d k[A]^{x}[B]^{y}$

Dengan konsentrasi awal

$A(0)=A_{0}, B(0)=B_{0}, C(0)=C_{0}, D(0)=D_{0}[3]$. 


\section{B. Model Oregonator}

Menurut Leigh seperti dikutip [4], pada tahun 1970 beberapa peneliti dari Universitas Oregon mulai mengembangkan suatu model yang dapat menjelaskan perilaku eksperimental dari reaksi Belousov - Zhabotinsky. Model yang dikenal sebagai model FKN disederhanakan menjadi model Oregonator.

Reaksi kimia yang digunakan untuk mendapatkan model Oregonator adalah sebagai berikut.

(R3) $\mathrm{BrO}_{3}^{-}+\mathrm{Br}^{-}+2 \mathrm{H}^{+} \rightarrow \mathrm{HBrO}_{2}+\mathrm{HOBr}$

(R2) $\mathrm{HBrO}_{2}+\mathrm{Br}^{-}+\mathrm{H}^{+} \rightarrow 2 \mathrm{HOBr}$

(G) $2 \mathrm{Ce}^{3+}+\mathrm{BrO}_{3}^{-}+\mathrm{HBrO}_{2}+3 \mathrm{H}^{+} \rightarrow 2 \mathrm{Ce}^{4+}+$ $2 \mathrm{HBrO}_{2}+\mathrm{H}_{2} \mathrm{O}$

(R4) $2 \mathrm{HBrO}_{2} \rightarrow \mathrm{BrO}_{3}^{-}+\mathrm{HOBr}+\mathrm{H}^{+}$

(R10) $4 \mathrm{Ce}^{4+}+\mathrm{BrMA}+2 \mathrm{H}_{2} \mathrm{O} \rightarrow 4 \mathrm{Ce}^{3+}+\mathrm{HCOOH}+$ $2 \mathrm{CO}_{2}+5 \mathrm{H}^{+}$

konsentrasi $\mathrm{BrO}_{3}^{-}, \mathrm{BrMA}$ dan $\mathrm{HOBr}$ adalah sama karena ketiga zat ini masuk dan keluar dari medium reaksi dengan laju konstan. Sebaliknya, konsentrasi $\mathrm{HBrO}_{2}, \mathrm{Br}^{-}$dan $\mathrm{Ce}^{4+}$ berubah seiring berjalannya waktu [5]. Selanjutnya, misalkan $\mathrm{X}=\left[\mathrm{HBrO}_{2}\right]$

$\mathrm{Y}=\left[\mathrm{Br}^{-}\right]$

$\mathrm{Z}=\left[\mathrm{Ce}^{4+}\right]$

$\mathrm{A}=\left[\mathrm{BrO}_{3}^{-}\right]$

$\mathrm{B}=[\mathrm{BrMA}]$

$\mathrm{P}=[\mathrm{HOBr}]$

Maka reaksinya menjadi

(M1) $A+Y \rightarrow X+P$

(M2) $X+Y \rightarrow 2 P$

(M3) $A+X \rightarrow 2 X+2 Z$

(M4) $2 X \rightarrow A+P$

$(M 5) B+Z \rightarrow f Y$

Dengan laju

$r_{(M 1)}=k_{R 3}\left[H^{+}\right]^{2} A Y$

$r_{(M 2)}=k_{R 2}\left[H^{+}\right] X Y$

$r_{(M 3)}=k_{R 5}\left[H^{+}\right] A X$

$r_{(M 4)}=k_{R 4} X^{2}$

$r_{(M 5)}=k_{0} B Z$

Dengan menggunakan hukum laju, didapat suatu sistem persamaan diferensial tak linier sebagai berikut.

$\frac{d X}{d t}=k_{3} A Y-k_{2} X Y+k_{5} A X-2 k_{4} X^{2}$

$\frac{d Y}{d t}=-k_{3} A Y-k_{2} X Y+f k_{0} B Z$

$\frac{d Z}{d t}=2 k_{5} A X-k_{0} B Z$

Dimana:

$\mathrm{X}=$ konsentrasi asam Bromat $/\left[\mathrm{HBrO}_{2}\right]$

$\mathrm{Y}=$ konsentrasi ion Bromida $/\left[\mathrm{Br}^{-}\right]$

$\mathrm{Z}=$ konsentrasi ion $\mathrm{Ce}(\mathrm{IV}) /\left[\mathrm{Ce}^{4+}\right]$

$\mathrm{A}=$ konsentrasi ion Bromat $/\left[\mathrm{BrO}_{3}^{-}\right]$

$\mathrm{B}=$ konsentrasi asam Bromo Malonat / $[\mathrm{BrMA}]$

$\mathrm{P}=$ konsentrasi asam Hipobromat / $[\mathrm{HOBr}]$

$f=$ konstanta stoikiometri

Berdasarkan [6], apabila digunakan suatu larutan dengan $\left[\mathrm{H}^{+}\right] \sim 1 \mathrm{M}$ pada $0.8 \mathrm{M} \mathrm{H}_{2} \mathrm{SO}_{4}$ dengan mengasumsikan konsentrasi awal

$A_{0}=\left[\mathrm{BrO}^{3-}\right]_{0}=0.06 \mathrm{M}$

$B_{0}=[B r M A]_{0}=10^{-3} M$

maka didapat nilai parameter yang ditunjukkan pada Tabel 1:
Tabel 1.

Parameter Model Oregonator [6]

\begin{tabular}{ccc}
\hline \hline \multirow{2}{*}{ Parameter } & Deskripsi & Nilai \\
\hline$k_{0}$ & Konstanta laju dari reaksi 5 & $0.4 \mathrm{M}^{-1} S^{-1}$ \\
$k_{2}$ & konstanta laju dari reaksi 2 & $2 \times 10^{9} M^{-1} S^{-1}$ \\
$k_{3}$ & konstanta laju dari reaksi 1 & $2 M^{-1} S^{-1}$ \\
$k_{4}$ & konstanta laju dari reaksi 4 & $4 \times 10^{7} M^{-1} S^{-1}$ \\
$k_{5}$ & konstanta laju dari reaksi 3 & $10^{4} M^{-1} S^{-1}$ \\
\hline \hline
\end{tabular}

\section{Kriteria Nilai Eigen}

Teorema 2.5.3.1.1 [7]

Diberikan persamaan diferensial $\dot{x}=A x$ dengan matriks $A$ berukuran $\mathrm{n} \times \mathrm{n}$ mempunyai nilai karakteristik yang berbeda $\lambda_{1}, \ldots, \lambda_{\mathrm{k}}(\mathrm{k} \leq \mathrm{n})$.

1. Titik asal $\bar{x}=0$ adalah stabil asimtotik bila dan hanya bila $\operatorname{Re}\left(\lambda_{i}\right)<0$ untuk semua $i=1,2, \ldots, k$.

2. Titik asal $\bar{x}=0$ adalah stabil bila dan hanya bila $\operatorname{Re}\left(\lambda_{i}\right) \leq 0$ untuk semua $i=1,2, \ldots, k$, dan untuk semua $\lambda_{i}$ dengan $\operatorname{Re}\left(\lambda_{i}\right)=0$ multiplisitas aljabar sama dengan multisiplitas geometrinya.

3. Titik asal $\bar{x}=0$ adalah tidak stabil bila dan hanya bila $\operatorname{Re}\left(\lambda_{i}\right)>0$ untuk beberapa $i=1,2, \ldots, k$, atau ada $\lambda_{i}$ dengan $\operatorname{Re}\left(\lambda_{i}\right)=0$ dengan multiplisitas aljabar lebih besar dari multiplisitas geometrinya.

\section{D.Aturan Tanda Descartes}

Diberikan suatu polinomial karakteristik

$$
p(\lambda)=a_{0} \lambda^{n}+a_{1} \lambda^{n-1}+\cdots+a_{n-1} \lambda+a_{n}=0
$$

Tanpa mengurangi keumuman, diasumsikan $a_{n}>0$. Misalkan $N$ adalah banyaknya perubahan tanda pada barisan koefisien $\left\{a_{n}, a_{n-1}, \ldots, a_{0}\right\}$ tanpa menghiraukan koefisien yang bernilai 0 . Aturan tanda Descartes menyatakan bahwa $p(\lambda)$ mempunyai paling banyak $N$ akar - akar yang real dan positif, dan lagi, ada $N, N-2$ atau $N-4, \ldots$ akar real positif [8].

\section{E. Kriteria Routh - Hurwitz}

Diberikan suatu polinomial $q(s)=a_{n} s^{n}+a_{n-1} s^{n-1}+\cdots+a_{1} s+a_{0}, a_{n} \neq 0$

Dari polinomial tersebut, dapat disusun suatu Tabel seperti yang dapat dilihat pada Tabel 2:

Tabel 2. Tabel Routh Hurwitz

\begin{tabular}{c|cccc}
\hline \hline$s^{n}$ & $a_{n}$ & $a_{n-2}$ & $a_{n-4}$ & $\ldots$ \\
$s^{n-1}$ & $a_{n-1}$ & $a_{n-3}$ & $a_{n-5}$ & $\ldots$ \\
$s^{n-2}$ & $b_{1}$ & $b_{2}$ & $b_{3}$ & \\
$s^{n-3}$ & $c_{1}$ & $c_{2}$ & $c_{3}$ & \\
$\vdots$ & $\vdots$ & & & \\
$s^{0}$ & $q$ & & & \\
\hline \hline
\end{tabular}

dimana $b_{1}, b_{2}, \ldots, c_{1}, c_{2}, \ldots$ dan $q$ secara rekursif didapatkan dari:

$$
\begin{gathered}
b_{1}=\frac{a_{n-1} a_{n-2}-a_{n} a_{n-3}}{a_{n-1}}, b_{1}=\frac{a_{n-1} a_{n-4}-a_{n} a_{n-5}}{a_{n-1}}, \ldots \\
c_{1}=\frac{b_{1} a_{n-3}-b_{2} a_{n-1}}{b_{1}}, \quad c_{2}=\frac{b_{1} a_{n-5}-b_{3} a_{n-1}}{b_{1}}, \ldots
\end{gathered}
$$

Kriteria Routh - Hurwitz menyimpulkan bahwa banyaknya perubahan tanda dalam kolom pertama pada tabel diatas sama dengan banyaknya akar - akar polinomial $q(s)$ yang bagian realnya positif [8].

\section{F. Orbit Periodik}

Untuk suatu medan vector $\dot{x}=f(x, y)$ 
$\dot{y}=g(x, y)$

Dimana $f, g \in C^{1}$ dengan $C^{1}$ merupakan himpunan fungsi kontinu yang turunan pertamanya juga kontinu, berlaku teorema berikut.

Teorema 2.5.4.1 [9]

Jika pada suatu daerah terhubung sederhana $D \subset \mathbb{R}^{2}$ (misalnya D tidak mempunyai lubang) $\frac{\partial f}{\partial x}+\frac{\partial g}{\partial y}$ tidak nol dan tidak berubah tanda, maka system tidak memiliki orbit tertutup yang terletak seluruhnya di D.

\section{G.Bifurkasi}

Bifurkasi adalah perubahan kualitatif dalam struktur asimtotik suatu sistem dinamik.

Definisi 2.7.1 [9]

Suatu titik tetap $(x, \mu)=(0,0)$ dari suatu keluarga vector fields satu dimensi dengan satu parameter dikatakan mengalami bifurkasi pada $\mu=0$ jika flow untuk $\mu$ disekitar 0 dan $x$ disekitar 0 tidak sama secara kualitatif dengan flow disekitar $x=0$ pada $\mu=0$.

Bifurkasi Hopf adalah bifurkasi periodik dimana suatu limit cycle baru muncul dari suatu solusi stasioner ketika suatu parameter melewati nilai kritis. Ketika limit cycle muncul, kestabilan dari solusi stasioner turut berubah. Bifurkasi Hopf hanya bisa terjadi pada dimensi 2 atau lebih.

Definisi 2.7.2 [9]

Misalkan $x_{0}$ adalah titik kesetimbangan regular untuk $\mu=$ $\mu_{0} . x_{0}$ disebut sebagai titik bifurkasi Hopf atau disingkat titik Hopf untuk $\mu=\mu_{0}$ jika dan hanya jika dua kondisi berikut terpenuhi:

1. Kondisi nilai eigen

$J$ mempunyai sepasang nilai eigen $\pm i \omega_{0}$ dimana $\omega \neq 0$ dan untuk $\mu=0$, tidak ada nilai eigen dari $\boldsymbol{J}$ yang merupakan nilai eigen regular.

2. Kondisi transversal

$$
\alpha^{\prime}\left(\mu_{0}\right) \neq 0
$$

(Dua kurva nilai eigen $\alpha(\mu) \pm i \beta(\mu)$ melintasi sumbu imajiner dengan kecepatan tak nol)

Pada bifurkasi Hopf, nilai - nilai eigen melewati sumbu imajiner. Titik merah pada gambar 2.4 mengindikasikan bifurkasi Hopf. Jika limit cycle yang muncul stabil, maka bifurkasi Hopf disebut supercritical, sedangkan jika limit cycle yang muncul tidak stabil, maka bifurkasi Hopf disebut subcritical. Periode dari limit cycle yang muncul diberikan oleh:

$$
T=\frac{2 \pi}{\left|\operatorname{Im}\left(\lambda\left(\mu_{0}\right)\right)\right|}
$$

\section{ANALISIS DAN PEMBAHASAN}

\section{A. Model Matematika Oregonator}

Dalam [6] diambil parameter tanpa dimensional:

$$
\begin{aligned}
& x=\frac{2 k_{4}}{k_{5} A} X \\
& y=\frac{k_{2}}{k_{5} A} Y \\
& z=\frac{k_{0} k_{4} B}{\left(k_{5} A\right)^{2}} Z \\
& \tau=k_{0} B t \\
& \varepsilon=\frac{k_{0}}{k_{5} A} B \\
& \delta=\frac{2 k_{0} k_{4}}{k_{2} k_{5} A} B \\
& q=\frac{2 k_{3} k_{4}}{k_{2} k_{5}}
\end{aligned}
$$

Maka didapat suatu system persamaan baru sebagai berikut:

$$
\begin{aligned}
& \frac{d x}{d \tau}=\frac{1}{\varepsilon}(q y-x y+x(1-x)) \\
& \frac{d y}{d \tau}=\frac{1}{\delta}(-q y-x y+2 f z) \\
& \frac{d z}{d \tau}=x-z
\end{aligned}
$$

Sistem (3.1) memiliki dua titik setimbang, yaitu $E_{1}^{*}=$ $(0,0,0)$ dan $E_{2}^{*}=\left(x^{*}, y^{*}, z^{*}\right)$ dimana

$$
\begin{aligned}
& x^{*}=\frac{1-f-q+\sqrt{1+q^{2}+4 f^{2}+2 q+12 q f-4 f}}{2} \\
& y^{*}=\frac{2 f\left(1-f-q+\sqrt{1+q^{2}+4 f^{2}+2 q+12 q f-4 f}\right)}{1+q-f+\sqrt{1+q^{2}+4 f^{2}+2 q+12 q f-4 f}} \\
& z^{*}=\frac{1-f-q+\sqrt{1+q^{2}+4 f^{2}+2 q+12 q f-4 f}}{2}
\end{aligned}
$$

Dengan $1-2 f-q>0$ dan $1+q^{2}+4 f^{2}+2 q+12 q f-$ $4 f>0$.

\section{B. Analisa Kestabilan}

Sistem dinamik model Oregonator pada (3.1) merupakan sistem yang tidak linier, sehingga untuk melakukan analisis kestabilan perlu dilakukan pelinieran di sekitar titik setimbangnya terlebih dahulu dengan membentuk matriks Jacobian. Matriks Jacobian dari sistem (3.1) di sekitar titik setimbang $E_{1}^{*}=(0,0,0)$ adalah:

$$
\boldsymbol{A}_{\mathbf{1}}=\left(\begin{array}{ccc}
\frac{1}{\varepsilon} & \frac{q}{\varepsilon} & 0 \\
0 & -\frac{q}{\delta} & \frac{2 f}{\delta} \\
1 & 0 & -1
\end{array}\right)
$$

Persamaan karakteristik dari matriks $A_{1}$ diberikan oleh

$\lambda^{3}+\left(\frac{\varepsilon(\delta+q)-\delta}{\varepsilon \delta}\right) \lambda^{2}+\left(\frac{q(\varepsilon+1)-\delta}{\varepsilon \delta}\right) \lambda-\left(\frac{q(2 f+1)}{\varepsilon \delta}\right)=0$

Berdasarkan aturan tanda Descartes dan kriteria nilai eigen, titik setimbang $E_{1}^{*}=(0,0,0)$ tidak stabil.

Matriks Jacobian dari sistem (3.1) di sekitar titik setimbang $E_{2}^{*}=\left(x^{*}, y^{*}, z^{*}\right)$ adalah:

$$
\boldsymbol{A}_{2}=\left(\begin{array}{ccc}
\frac{-y^{*}+1-2 x^{*}}{\varepsilon} & \frac{q-x^{*}}{\varepsilon} & 0 \\
\frac{-y^{*}}{\delta} & -\frac{q+x^{*}}{\delta} & \frac{2 f}{\delta} \\
1 & 0 & -1
\end{array}\right)
$$

Persamaan karakteristik dari matriks $A_{2}$ diberikan oleh $\lambda^{3}+A \lambda^{2}+B \lambda+C=0$

Dimana:

$A=\frac{\frac{x^{* 2}+q\left(x^{*}+2 f\right)}{q+x^{*}}}{\varepsilon}+\frac{q+x^{*}}{\delta}+1>0$

$B=\frac{\frac{x^{* 2}+q\left(x^{*}+2 f\right)}{q+x^{*}}}{\varepsilon}+\frac{q+x^{*}}{\delta}+\frac{\left(\frac{x^{2}+q\left(x^{*}+2 f\right)}{q+x^{*}}\right)\left(q+x^{*}\right)+\frac{2 f x^{*}}{q+x^{*}}\left(q-x^{*}\right)}{\varepsilon \delta}$

$C=\frac{x^{* 2}+q(1+2 f)}{\varepsilon \delta}>0$

Berdasarkan kriteria Routh - Hurwitz, kestabilan sistem dipengaruhi oleh $B$. Apabila $B>0$, sistem stabil dan supaya sistem stabil haruslah $A B-C>0$. Apabila $B<0$, sistem tidak stabil dan supaya sistem stabil haruslah $A B-C<0$.

Titik setimbang $E_{2}^{*}=\left(x^{*}, y^{*}, z^{*}\right)$ mengalami bifurkasi ketika $A B-C=0$ dengan nilai eigen $\lambda_{1}=-A, \lambda_{2,3}=$ $\pm i \sqrt{\frac{C}{A}}$.

\section{Orbit Periodik}

Asumsikan perubahan konsentrasi $Z$ adalah konstan, dimisalkan $M$, dengan $M>0$, sehingga didapat:

$f(x, y, \tau)=\frac{d x}{d \tau}=\frac{1}{\varepsilon}(q y-x y+x(1-x))$
$g(x, y, \tau)=\frac{d y}{d \tau}=\frac{1}{\delta}(-q y-x y+f x-f M)$ 
Dari sistem (3.2) didapat;

$\frac{\partial f}{\partial x}+\frac{\partial g}{\partial y}=\left(\frac{1}{\varepsilon}(-y+1-2 x)\right)+\left(\frac{1}{\delta}(-q-x)\right)$

$\frac{\partial f}{\partial x}+\frac{\partial g}{\partial y}=\frac{-y \delta-x(2 \delta+\varepsilon)+\delta-q \varepsilon}{\varepsilon \delta}$

Karena $x, y, \varepsilon, \delta, q>0$ dan $\delta \ll \varepsilon$, maka

$\frac{\partial f}{\partial x}+\frac{\partial g}{\partial y}=\frac{-y \delta-x(2 \delta+\varepsilon)+\delta-q \varepsilon}{\varepsilon \delta}<0$

Karena $\frac{\partial f}{\partial x}+\frac{\partial g}{\partial y} \neq 0$ dan tidak berubah tanda, maka menurut

Kriteria Bendixson system tidak mempunyai orbit tertutup yang berada seluruhnya di suatu daerah $D \subset \mathbb{R}^{2}$.

Selanjutnya dengan mengasumsikan bahwa

$\frac{\partial f}{\partial x}+\frac{\partial g}{\partial y}=0$

$\frac{\partial f}{\partial x}+\frac{\partial g}{\partial y}=\frac{-y \delta-x(2 \delta+\varepsilon)+\delta-q \varepsilon}{\varepsilon \delta}=0$

Didapat

$x=\frac{\delta(1-y)-q \varepsilon}{2 \delta+\varepsilon}$

Kedua garis tersebut membagi bidang menjadi tiga bidang terpisah, yaitu $R_{1}: x<x_{1}, R_{2}: x_{1}<x<x_{2}$ dan $R_{3}: x>x_{2}$.

Berdasarkan kriteria Bendixson, sistem (3.2) tidak mempunyai orbit periodik yang terletak sepenuhnya pada $R_{1}, R_{2}$ atau $R_{3}$, tapi tidak menutup kemungkinan bahwa sistem (3.2) mempunyai orbit periodic yang terletak di gabungan dari dua atau lebih bidang - bidang tersebut $\left(R_{1}, R_{2}\right.$ dan $R_{3}$ ).

\section{D.Analisis Bifurkasi}

Ketika $A B-C=0$, didapat nilai eigen

$\lambda_{1}=-\frac{\frac{x^{*}+q\left(x^{*}+2 f\right)}{q+x^{*}}}{\varepsilon}-\frac{q+x^{*}}{\delta}-1$

$\lambda_{2,3}= \pm i \sqrt{\frac{\left(q+x^{*}\right)\left(q+x^{*}\right)+2 f\left(q+x^{*}\right)}{2 q \delta f+\delta x\left(q+x^{*}\right)+\varepsilon\left(q+x^{*}\right)\left(q+x^{*}+1\right)}}$

Dapat dilihat bahwa $A$ dan $C$ adalah fungsi dari $q, \varepsilon, \delta, f$ dan $x^{*}$ dimana $q, \varepsilon, d$ adalah parameter tanpa dimensi dan $x^{*}$ adalah titik setimbang dan merupakan fungsi dari $f$ dan $q$. Nilai parameter tanpa dimensi $q, \varepsilon, \delta$ bergantung pada reaksi yang ada pada tabel 2.1 sedangkan nilai $f$ tidak bergantung pada laju reaksi ataupun reaktan, sehingga $f$ dapat dianggap sebagai parameter bebas [2]. Oleh karena itu, akan diambil $f$ sebagai parameter bifurkasi.

Karena $\boldsymbol{A}_{\mathbf{2}}$ mempunyai sepasang nilai eigen dengan bagian real 0 , maka kondisi nilai eigen dari definisi Hopf terpenuhi. Setelah dilakukan analisa terhadap turunan total dari persamaan karakteristik $\boldsymbol{A}_{2}$ didapatkan $\operatorname{Re}\left(\frac{d}{d f} \lambda\left(f_{0}\right)\right)>$ 0 sehingga kondisi transversalitas terpenuhi dan limit cycle yang muncul memiliki periode

$$
T=\frac{2 \pi}{\sqrt{\frac{\left(q+x^{*}\right)\left(q+x^{*}\right)+2 f\left(q+x^{*}\right)}{2 q \delta f+\delta x\left(q+x^{*}\right)+\varepsilon\left(q+x^{*}\right)\left(q+x^{*}+1\right)}}} .
$$

Dari hasil analisa kestabilan, diketahui bahwa sistem mengalami bifurkasi ketika

$A B-C=0$

$B=\frac{C}{A}>0$

Sesuai dengan hasil analisa tabel Routh - Hurwitz, ketika $B>0$ kondisi yang harus dipenuhi supaya sistem tidak stabil diberikan oleh:

$A B-C<0$

$\frac{N \delta^{2}+M \delta+L}{\delta^{2}}<0$

Dengan

$$
\begin{aligned}
& N=\frac{\left(x^{* 2}+q\left(x^{*}+2 f\right)\right)\left(1+\frac{x^{* 2}+q\left(x^{*}+2 f\right)}{\varepsilon\left(q+x^{*}\right)}\right)}{\varepsilon\left(q+x^{*}\right)}, \\
& M= \\
& \frac{\frac{x^{*}\left(2 x^{*}+3 q\right)+q(4 f-1)}{\varepsilon}+\frac{\left(x^{* 2}+q\left(x^{*}+2 f\right)\right)^{2}}{\varepsilon^{2}\left(q+x^{*}\right)}+\frac{2 f x^{*}\left(q-x^{*}\right)\left(x^{* 2}+q\left(x^{*}+2 f\right)\right)}{\varepsilon^{2}\left(q+x^{*}\right)^{2}}+\frac{2 f x^{*}\left(q-x^{*}\right)}{\varepsilon\left(q+x^{*}\right)}+\left(q+x^{*}\right)}{\delta}, \\
& L=\left(q+x^{*}\right)\left(\left(q+x^{*}\right)+\frac{x^{*}(1-q-4 f)+2 q(1+3 f)}{\varepsilon}\right) .
\end{aligned}
$$

sehingga

$N \delta^{2}+M \delta+L<0$

$\left(\delta-\left(\frac{-M+\sqrt{M^{2}-4 N L}}{2 N}\right)\right)\left(\delta-\left(\frac{-M-\sqrt{M^{2}-4 N L}}{2 N}\right)\right)<0$

Supaya $\delta$ bernilai real, maka kondisi berikut harus terpenuhi:

$M^{2}-4 N L>0$

Karena $M^{2}>0$ dan $N>0$, maka haruslah:

$L<0$

$\left(q+x^{*}\right)\left(\left(q+x^{*}\right)+\frac{x^{*}(1-q-4 f)+2 q(1+3 f)}{\varepsilon}\right)<0$

$\left(1-2 f-q+\sqrt{(1-q-2 f)^{2}+4 q(2 f+1)}\right)(1-q-4 f)+$ $4 q(1+3 f)<0$

(3.3)

Untuk suatu nilai $q$ yang sangat kecil, didapat

$(1-2 f)(1-4 f)<0$

Penyelesaian dari (3.3) juga merupakan rentang nilai $f$ supaya sistem tidak stabil diberikan oleh:

$$
\frac{1}{4}<f<\frac{1}{2}
$$

\section{SIMULASI DAN ANALISIS}

Simulasi ini akan menunjukkan pengaruh perubahan nilai parameter $f$ terhadap osilasi yang terjadi pada reaksi B-Z.

Nilai parameter yang digunakan adalah

$\varepsilon=5 \times 10^{-5}$

$\delta=2 \times 10^{-4}$

$q=8 \times 10^{-4}$

Dari [3] didapat:

$x_{0} \approx 1.27 \times 10^{-7} M$

$y_{0} \approx 6 \times 10^{-7} M$

$z_{0} \approx 5 \times 10^{-3} M$

1. $f=0.1$

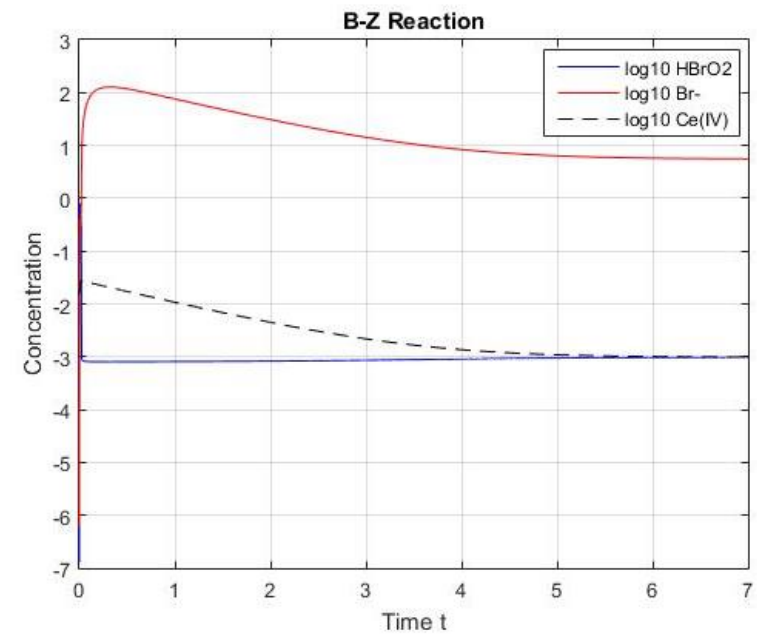

Gambar 1. Simulasi untuk $f=0.1$.

Karena $f<0.25$, maka reaksi stabil. Titik setimbang sistem adalah $E_{2}^{*}=(0.798,0.2,0.798)$, yang berarti reaksi 
mencapai kesetimbangan ketika konsentrasi $\mathrm{HBrO}_{2}$ dan $\mathrm{Ce}(\mathrm{IV})$ sebesar $0.798 \mathrm{M}$, dan konsentrasi $\mathrm{Br}^{-}$sebesar $0.2 \mathrm{M}$.

Pada awal reaksi, konsentrasi $\mathrm{HBrO}_{2}$ mengalami kenaikan yang paling tinggi, menandakan bahwa $\mathrm{HBrO}_{2}$ banyak dihasilkan. Setelah itu, konsentrasi $\mathrm{HBrO}_{2}$ menurun secara drastis sedangkan konsentrasi $\mathrm{Br}^{-}$naik secara drastis dan $\mathrm{Ce}(\mathrm{IV})$ naik sedikit, menandakan $\mathrm{HBrO}_{2}$ banyak digunakan sebagai reaktan sementara $\mathrm{Br}^{-}$banyak dihasilkan dan $\mathrm{Ce}(\mathrm{IV})$ dihasilkan sedikit. Setelah itu, konsentrasi $\mathrm{Br}^{-}$tetap naik sedangkan konsentrasi $C e(I V)$ mulai turun, menandakan $\mathrm{Br}^{-}$dihasilkan sedikit dan $\mathrm{Ce}(\mathrm{IV})$ digunakan sebagai reaktan. Konsentrasi $\mathrm{Br}^{-}$mulai turun segera setelah satuan waktu ke 0.9. Seiring berjalannya waktu, konsentrasi $\mathrm{Br}^{-}$dan $\mathrm{Ce}(\mathrm{IV})$ terus turun, sedangkan konsentrasi $\mathrm{HBrO}_{2}$ mulai naik setelah satuan waktu keempat. Saat konsentrasi $\mathrm{HBrO}_{2}$ dan Ce(IV) sama pada satuan waktu keenam, konsentrasi ketiganya menjadi konstan, menandakan reaksi menjadi setimbang.

\section{2. $f=0.2$}

Karena $f<0.25$, maka reaksi stabil. Titik setimbang sistem adalah $E_{2}^{*}=(0.598,0.399,0.598)$ yang berarti reaksi mencapai kesetimbangan ketika konsentrasi $\mathrm{HBrO}_{2}$ dan $\mathrm{Ce}(\mathrm{IV})$ sebesar $0.598 \mathrm{M}$, dan konsentrasi $\mathrm{Br}^{-}$sebesar $0.399 \mathrm{M}$.

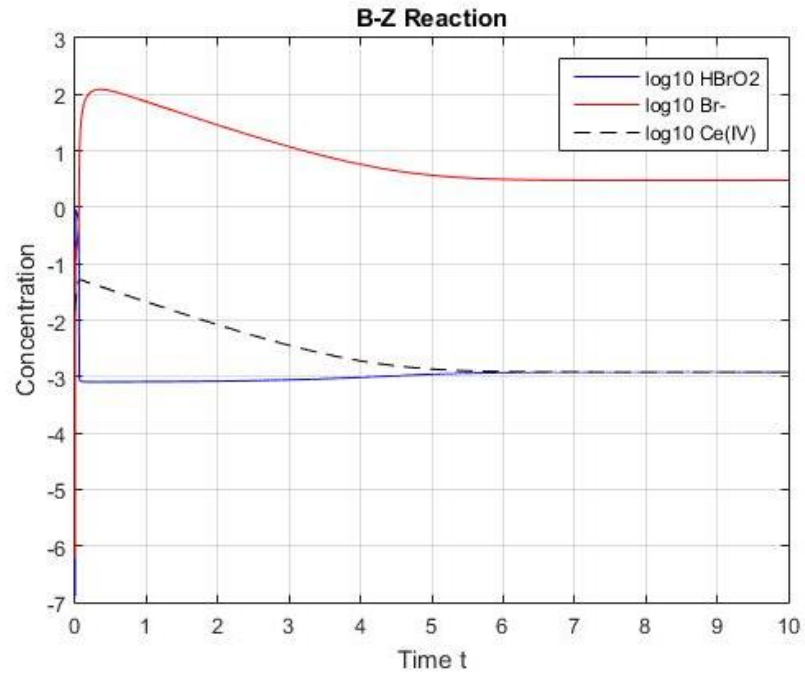

Gambar 2. Simulasi untuk $f=0.2$

Gambar 2 hampir sama seperti gambar 4.1, namun penurunan konsentrasi $\mathrm{HBrO}_{2}$ dan kenaikan konsentrasi $\mathrm{Br}^{-}$ dan $C e(I V)$ pada saat $f=0.2$ terjadi lebih lambat. Setelah itu, konsentrasi $\mathrm{Br}^{-}$tetap naik sedangkan konsentrasi $\mathrm{Ce}(\mathrm{IV})$ mulai turun, menandakan $\mathrm{Br}^{-}$dihasilkan sedikit dan $\mathrm{Ce}(\mathrm{IV})$ digunakan sebagai reaktan. Konsentrasi $\mathrm{Br}^{-}$mulai turun sebelum satuan waktu ke 0.9. Seiring berjalannya waktu, konsentrasi $\mathrm{Br}^{-}$dan $\mathrm{Ce}(\mathrm{IV})$ terus turun, sedangkan konsentrasi $\mathrm{HBrO}_{2}$ mulai naik sebelum satuan waktu keempat. Saat konsentrasi $\mathrm{HBrO}_{2}$ dan $\mathrm{Ce}(\mathrm{IV})$ sama, sebelum satuan waktu keenam, konsentrasi ketiganya menjadi konstan, menandakan reaksi menjadi setimbang. Jika dibandingkan dengan simulasi sebelumnya, ketika $f=0.2$ reaksi menjadi setimbang sedikit lebih cepat.

3. $f=0.3$

Karena $f<0.25$, maka reaksi stabil. Titik setimbang sistem adalah $E_{2}^{*}=(0.396,0.599,0.396)$ yang berarti reaksi mencapai kesetimbangan ketika konsentrasi
$\mathrm{HBrO}_{2}$ dan $\mathrm{Ce}(\mathrm{IV})$ sebesar $0.396 \mathrm{M}$, dan konsentrasi $\mathrm{Br}^{-}$sebesar $0.599 \mathrm{M}$.

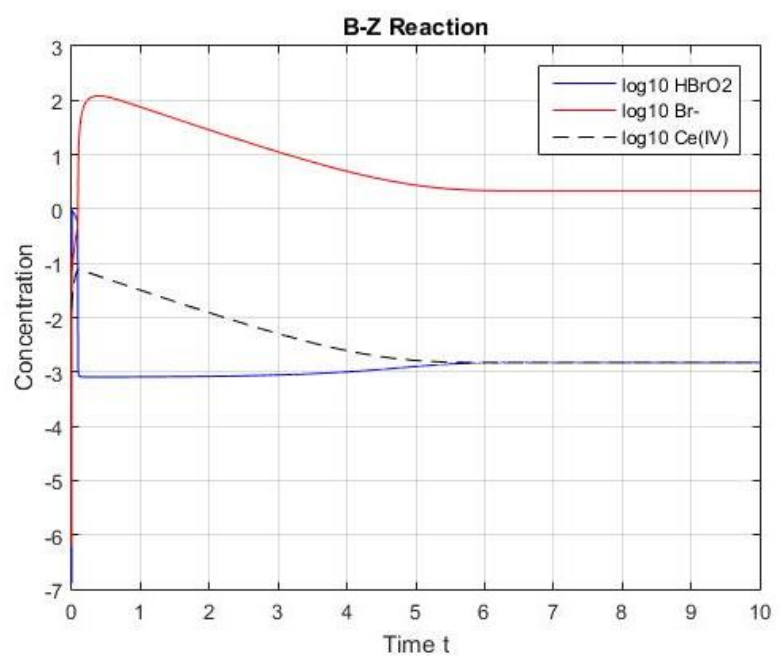

Gambar 2. Simulasi untuk $f=0.3$.

Gambar 3 juga hampir sama dengan dengan gambar 4.2, namun penurunan konsentrasi $\mathrm{HBrO}_{2}$ dan kenaikan konsentrasi $\mathrm{Br}^{-}$dan $\mathrm{Ce}(\mathrm{IV})$ pada saat $f=0.3$ terjadi lebih lambat. Setelah itu, konsentrasi $B r^{-}$tetap naik sedangkan konsentrasi $\mathrm{Ce}(\mathrm{IV})$ mulai turun, menandakan $\mathrm{Br}^{-}$dihasilkan sedikit dan $C e(I V)$ digunakan sebagai reaktan. Konsentrasi $\mathrm{Br}^{-}$mulai turun sebelum satuan waktu ke 0.9. Jika dibandingkan dengan simulasi sebelumnya, ketika $f=0.3$ reaksi menjadi setimbang sedikit lebih cepat.

4. $f=0.4$

Karena $0.25<f<\frac{1+\sqrt{2}}{2}$, maka reaksi tidak stabil. Titik setimbang sistem adalah $E_{2}^{*}=(0.192,0.797,0.192)$ yang berarti reaksi mencapai kesetimbangan ketika konsentrasi $\mathrm{HBrO}_{2}$ dan $\mathrm{Ce}(\mathrm{IV})$ sebesar $0.192 \mathrm{M}$, dan konsentrasi $\mathrm{Br}^{-}$ sebesar $0.797 M$. Limit cycle yang muncul memiliki periode $T=6822.44$.

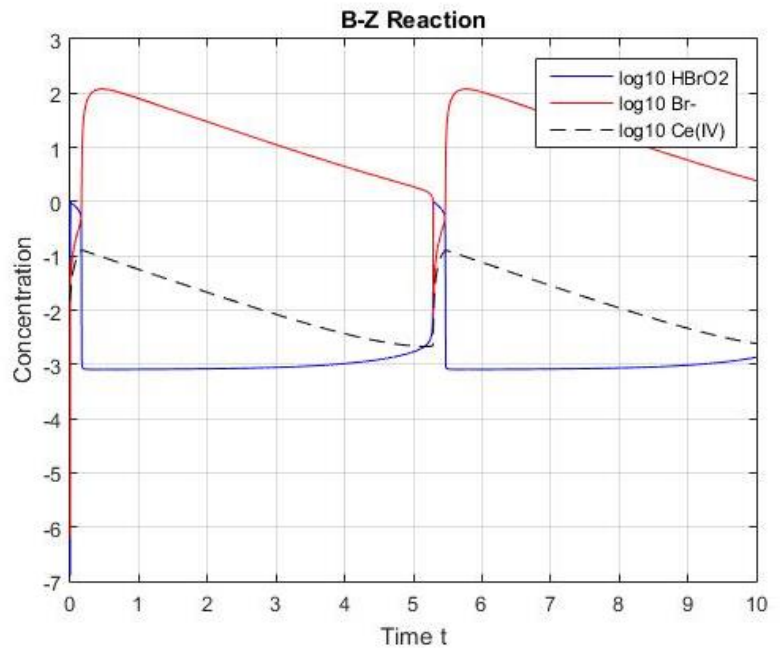

Gambar 4. Simulasi untuk $f=0.4$.

Ketika $f=0.4$, konsentrasi $\mathrm{HBrO}_{2}, \mathrm{Br}^{-}$dan $\mathrm{Ce}(\mathrm{IV})$ naik dan turun secara berulang - ulang dan sistem tidak kunjung setimbang. Naik turunnya konsentrasi $\mathrm{HBrO}_{2}, \mathrm{Br}^{-}$dan $\mathrm{Ce}(I V)$ ini dapat diamati sebagai munculnya perubahan warna yang membentuk suatu pola pada reaksi saat eksperimen dilakukan. Warna yang muncul pada eksperimen berasal dari ion $\mathrm{Ce}(I I I)$ dan $\mathrm{Ce}(\mathrm{IV})$. Oleh karena $\mathrm{Ce}(I I I)$ diubah menjadi $C e(I V)$ dan $C e(I V)$ diubah menjadi $C e(I I I)$ 
secara terus - menerus, muncullah perubahan warna yang akhirnya membentuk suatu pola tertentu. Perubahan $C e(I I I)$ menjadi $C e(I V)$ dan sebaliknya yang terus - menerus menandakan bahwa kelima reaksi terjadi secara berkesinambungan dan terus - menerus. Bidang fase untuk $f=0.4$ ditunjukkan oleh Gambar 5, 6 dan 7 .

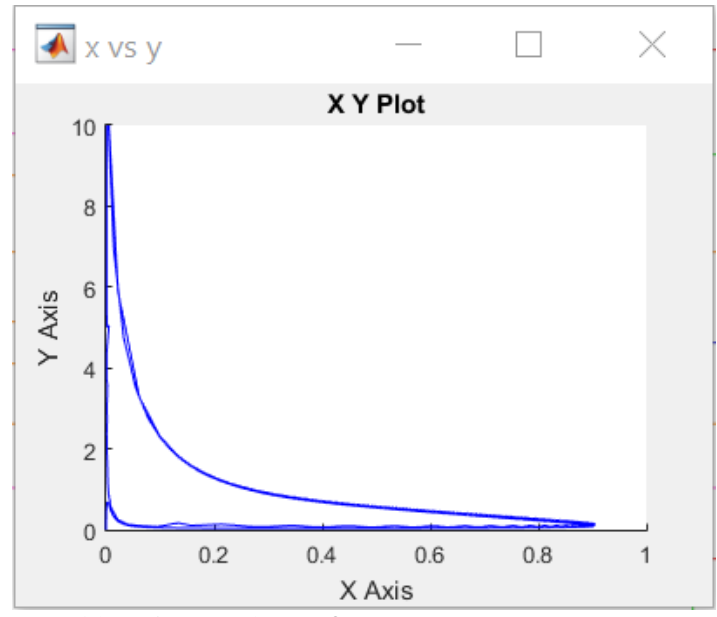

Gambar 3. Bidang fase untuk $\mathrm{HBrO}_{2}$ vs. $\mathrm{Br}^{-}$.

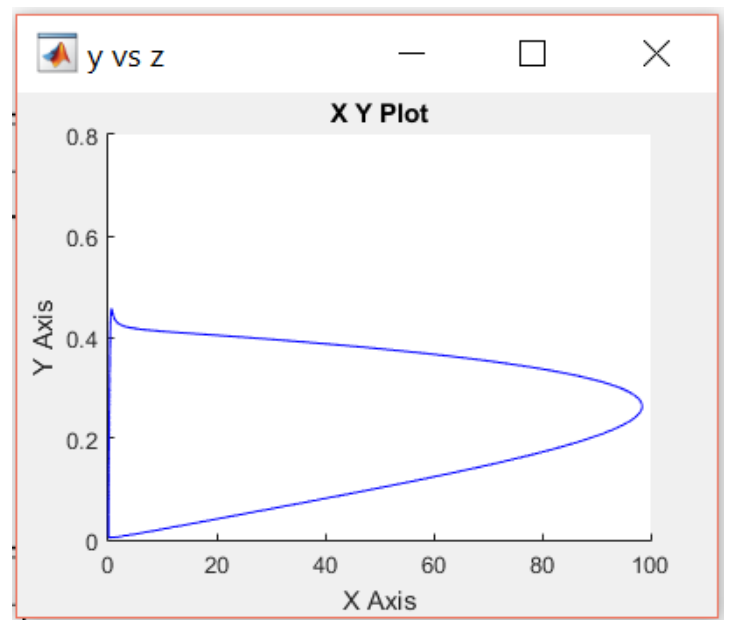

Gambar 4. Bidang fase untuk $\mathrm{Br}^{-}$vs. $\mathrm{Ce}(\mathrm{IV})$.

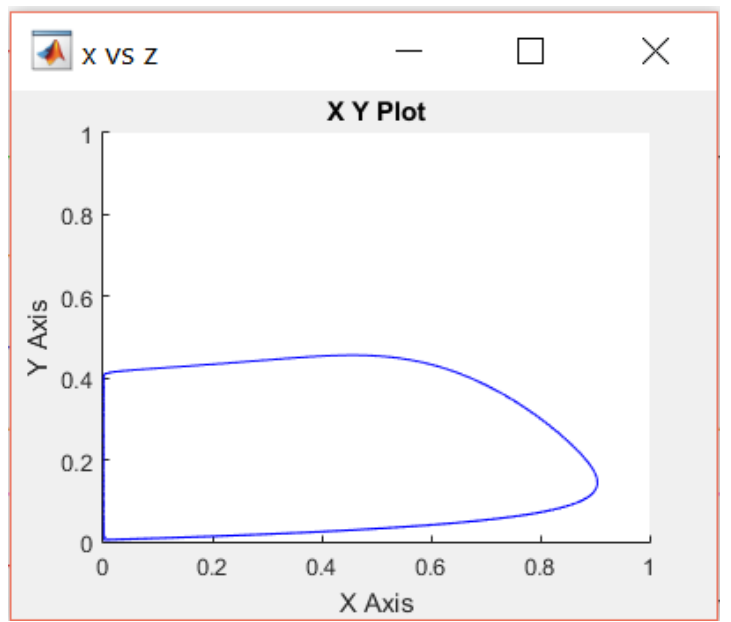

Gambar 5. Bidang fase untuk $\mathrm{HBrO}_{2}$ vs. $\mathrm{Ce}(\mathrm{IV})$.
1) Model oregonator memiliki dua titik kesetimbangan, yaitu:

$E_{1}^{*}=(0,0,0)$ dan

$E_{2}^{*}=\left(x^{*}, y^{*}, z^{*}\right)$

dimana:

$x^{*}=\frac{1-2 f-q+\sqrt{1+q^{2}+4 f^{2}+2 q+12 q f-4 f}}{2}$,

$y^{*}=\frac{2 f\left(1-f-q+\sqrt{1+q^{2}+4 f^{2}+2 q+12 q f-4 f}\right)}{1+q-f+\sqrt{1+q^{2}+4 f^{2}+2 q+12 q f-4 f}}$,

$Z^{*}=\frac{1-2 f-q+\sqrt{1+q^{2}+4 f^{2}+2 q+12 q f-4 f}}{2}$

Dengan $f<\frac{1-q}{2}$ dan $1+q^{2}+4 f^{2}+2 q+12 q f-$ $4 f>0$.

2) Titik setimbang $E_{1}^{*}=(0,0,0)$ tidak stabil sedangkan pada titik setimbang $E_{2}^{*}=\left(x^{*}, y^{*}, z^{*}\right)$ terjadi bifurkasi.

3) Bifurkasi yang terjadi pada titik setimbang $E_{2}^{*}=$ $\left(x^{*}, y^{*}, z^{*}\right)$ adalah bifurkasi Hopf dan sistem mengalami osilasi apabila nilai $f$ berada pada rentang $\frac{1}{4}<f<\frac{1}{2}$.

4) Dari hasil simulasi, untuk sistem yang stabil semakin kecil nilai $f$, semakin sedikit pula waktu yang dibutuhkan untuk sistem menjadi setimbang.

\section{DAFTAR PUSTAKA}

[1] N. Shanks, "Modeling Biological Systems: The BelousovZhabotinsky Reaction," Found. Chem., vol. 3, no. 1, pp. 33-53, 2001.

[2] C. Gray, "An Analysis of the Belousov-Zhabotinskii Reaction," 2002.

[3] R. Chang, Chemistry. New York: Mc Graw - Hill Inc, 2010.

[4] X. Wang, Y. Chang, and D. Xu, "Bifurcation Analysis of a Belousov-Zhabotinsky Reaction Model," Int. J. Bifurc. Chaos, vol. 25 , no. 6 , p. 1550093 , Jun. 2015 .

[5] M. Dodd, "The Belousov-Zhabotinsky Oscillator: An Overview," 2010

[6] J. Tyson, Lecture Notes in Biomethematics, 1st ed. Berlin Springer, 1976.

[7] Subiono, "Sistem Linear dan Kontrol Optimal," 2013. [Online] Available: https://docplayer.info/30430283-Sistem-linear-dankontrol-optimal.html. [Accessed: 28-Mar-2019].

[8] J. Murray, Mathematical Biology, 3rd ed. New York: Springer, 2002

[9] S. Wiggins, "Introduction," in Introduction to Applied Nonlinear Dynamical Systems and Chaos, New York: Springer-Verlag, 2003, pp. $1-4$.

\section{V.KESIMPULAN}

Kesimpulan yang didapat dari penelitian ini adalah: 